\title{
Impact of an Educational Program on Pediatric Nurses Knowledge Regarding Non-Pharmacological Pain Management in Neonatal Intensive Care Units
}

\author{
Amal Ahmed Khalil ${ }^{1}$; Nabila Hassan Abed-Ella ${ }^{2}$; Nagwa Rizk Mohamed ${ }^{3}$; Hala \\ Samir El-husseiny ${ }^{4}$ \\ Professor of Pediatric Nursing ${ }^{1}$, Lecturer of Pediatric Nursing ${ }^{2}$, Lecturer of Pediatric \\ Nursing ${ }^{3}$, Assistant lecturer of Pediatric Nursing ${ }^{4}$, Faculty of Nursing, Port Said \\ University
}

\begin{abstract}
Background: Neonates in the NICUs are exposed to a number of painful procedures. Non-pharmacological treatment methods are effective to prevent and relieve the pain in newborns Aim: This study was aimed to improve nurses' knowledge regarding nonpharmacological management of pain in newborns in neonatal intensive care units. Subjects and Method: A quasi-experimental research design was utilized in this study. The subject of the study compromised all the nurses working in the NICUs in Port Said hospitals $(\mathrm{N}=40)$. The data were collected using a questionnaire sheet Conclusion: The study revealed that, after the educational program, more than half of the studied nurses had satisfactory knowledge regarding non- pharmacological pain management in newborn Recommendations: continuous training courses should be provided to nurses in order to keep their knowledge regarding non-pharmacological pain management up to date. Also, nurses should be encouraged to attend national and international conferences and workshops about non-pharmacological management for newborns.
\end{abstract}

Keywords: non-pharmacological, pain management, neonates, NICU, nurses, educational program 


\section{INTRODUCTION}

Non-pharmacological management is effective in reducing mild to moderate pain (Abdallah et al., 2013) and agitation (Naughton, 2013) in addition to decreasing crying time following acute episodes of mild pain, like heel sticks and oral gastric tube insertion (Hall, 2012). Non-pharmacological strategies include non-nutritive sucking (NNS), oral sucrose, swaddling, positioning, facilitated tucking (FT), holding and rocking, breast or bottle feeding, kangaroo care or skin to skin contact, multi-sensorial stimulation (SS) and reduction in noxious stimuli - irritant touch, bright lights and noise music (Chidambaram et al., 2014; Bellieni et al., 2016). These strategies stimulate the newborn in relevant developmental systems, such as oral, vestibular and motor ones. Moreover, the breastfeeding and the skin to-skin contact comprises a part of the whole process of parenting, acting for pain relief and promoting the mother-child interactions, which are imperative for the emotional development of newborns (Craig et al., 2015; Phillips, 2015).

Healthcare professionals are responsible for influencing positive changes in clinical practices about neonatal pain (Walden and Gibbins, 2013). Healthcare institutions should develop and implement patient care policies to assess, prevent, and manage pain in neonates (Kliegman et al., 2016).

The National Association of Neonatal Nurses (NANN) in America have recommended routine pain assessment, minimized painful procedures, and application of pharmacological and non-pharmacological therapies to prevent and eliminate pain in neonates (National Association of Neonatal Nurses, 2012).

There is an increasing number of evidence, both nationally and internationally, in studies of pain management practices in newborns, which shows infrequent use of nonpharmacological strategies, and also suggests that many newborns did not receive pain treatment during commonly performed painful procedures (Roofthooft et al., 2014). 


\section{Significance of the study:}

Non-pharmacological management is an important step toward effective pain relief in newborns. Nurses who do not recognize non-pharmacological management increase the suffering of neonates. Therefore, the importance of pain management in the clinical setting can also be viewed as part of good-quality nursing care.

\section{AIM OF STUDY:}

The program aimed to improve nurses' knowledge regarding non-pharmacological management of pain among newborns in neonatal intensive care units.

\section{SUBJECTS AND METHOD:}

\section{Research design}

A quasi-experimental research design was utilized in this study

\section{Study setting:}

The study was conducted at the neonatal intensive care units (NICU) at Port Said hospitals affiliated to the Ministry of Health, including El-Nasr general hospital, Port Said general hospital, Port Fouad general hospital and El-Tadamon health insurance hospital.

\section{Study subjects:}

The subjects of the current study included all the nurses working in the previously mentioned settings in NICU regardless their years of experience or qualifications (convenience sample). The number of subjects was 40 in pre- and post-intervention phases and 34 in follow-up phase.

\section{Tool of data collection:}

\section{Tool I:}

Structured interview questionnaire sheet:

This tool was designed by the researcher, after reviewing pertinent literature to collect information from the nurses. It consisted of the following 3 parts: 


\section{Part I:}

This part included questions concerning the characteristics of the studied nurses such as age, level of education, years of experience in neonatal nursing, marital status, number of children, and attending previous training programs concerning the non-pharmacological methods of pain management in newborns.

\section{Part II:}

This part was concerned with nurses' knowledge regarding methods of nonpharmacological management used to relieve pain in newborns, like: non-nutritive sucking (NNS) , swaddling, soothing vocalization ,auditory material, baby's perfume on the nurse's hands, positive touching, facilitate tucking, holding, rhythmic rocking, partial massage, breast milk by bottle, put the newborn in nesting inside incubator

\section{Pilot Study:}

A pilot study was carried out on 4 nurses working at El-Nasr general hospital's NICU. The purpose of the pilot study was to test the applicability, clarity, relevance, and feasibility of the study tools and the sequence of questions to maintain consistency. The pilot study also helped estimate the time needed to complete the tools. Afterwards, the necessary modifications were done and the final form of the tools was developed. The subjects in the pilot study were excluded from the final study sample.

\section{Method of Data Collection:}

- Data collection took place in the selected settings from the beginning of January 2016 till the end of January 2017. The pre-test was done from $1^{\text {st }}$ of January to the end of February 2016, while the post-test was done from $1^{\text {st }}$ of July to the end of August 2016, and the follow up was done 3 months after the post-test $\left(1^{\text {st }}\right.$ of December 2016 to the end of January 2017).

- The researcher was available during each of the study phases 3 days per week. From 2 to 3 nurses were interviewed per day. Each nurse was individually interviewed to assess her knowledge about pain using a structured interview which took 15 to 20 minutes, Different teaching methods strategies were implemented, such as traditional modified lectures, demonstration, re-demonstration and group discussions. Audiovisual materials were also used to further explain some topics. 
- The application of the program was carried out at the NICU departments in the selected study settings. The program was implemented in 6 sessions; the duration of each one lasted from 40 to 50 minutes. The study sample was divided into multiple groups, with 2-3 nurses in each session. There were 3 sessions per week according to the number of nurses in each hospital. The educational program was completely implemented within 4 months (without post-test), from 1st of March to the end of June 2016.

- The educational program also included knowledge about non-pharmacological management of pain in newborns regarding its definition, benefits and methods of non-pharmacological management included (non-nutritive sucking (NNS), swaddling, soothing vocalization, auditory material, baby's perfume on the nurse's hands, positive touching, facilitate tucking, holding, rhythmic rocking, partial massage, breast milk by bottle, put the newborn in nesting inside incubator).

- The nurses were evaluated 3 times; before the program application, immediately after the program's implementation, and 3 months later.

\section{Administrative Design:}

Official letters were issued from the Dean of the Faculty of Nursing, Port Said University to the directors and heads of the NICU departments of the governmental and health insurance hospitals in Port Said to obtain their permission for conducting the study.

\section{Ethical Considerations:}

Written permission for collection of data was obtained from the directors of the study setting hospitals after explaining the aim of the study. Also, the aim was explained to each nurse participant to clarify the importance of her participation in the study. The researcher promoted the confidentiality of the collected data and assured the study sample that the information obtained during the study was to be used only for the purpose of the study, also the researcher clarified to the nurses that they were free to withdraw from the study at any time. 


\section{Statistical Design:}

\section{Scoring System:}

The studied nurses' answers were compared with a model key, where (1) score was given for every point stated right, and (0) was given for "do not know".

According to the nurses' responses, their level of knowledge was categorized as: satisfactory $(\geq 60 \%)$ and unsatisfactory $(<60 \%)$.

\section{Statistical Analysis:}

Descriptive statistics including frequency and distribution were used to describe different characteristics. Qualitative variables were compared by using Chi-Square test or Fisher's exact test before/immediately and after within one group. The significance of the results was evaluated at $\leq 0.05 \%$ level of significance.

\section{RESULTS:}

Table (1): illustrated the characteristics of the studied nurses, and showed that more than half of the studied nurses (62.5\%) aged between 20 to less than 25 years, $57.5 \%$ of them graduated from technical nursing institutes, while $15.0 \%$ had baccalaureate nursing degrees. Regarding marital status, $57.5 \%$ of the nurses were married, and more than three quarter $(76.0 \%)$ had children.

Moreover, it was revealed that more than half of the studied nurses $(60.0 \%)$ had 1 to less than 3 years' experience in NICU, and one third of them (30.0\%) attended courses about nonpharmacological pain management in newborns.

Table (2): demonstrated nurses' knowledge about non-pharmacological management of pain in newborns. It was revealed that at the pre-intervention phase, only $15 \%$ of the studied nurses mentioned the definition of non-pharmacological management of pain in newborns. Moreover, the most frequent methods reported by them were: non-nutritive sucking $(30 \%)$, partial massage $(17.5 \%)$, oral sucrose $(15 \%)$, and decreased light and noise $(15 \%)$. The post-intervention phase showed statistically significant $(\mathrm{P} \leq 0.0001)$ improvements, where $97.5 \%$ of the studied nurses described non-nutritive sucking as a non-pharmacological pain management approach in newborns, while 95\% mentioned 
both oral sucrose and swaddling, 92.5\% stated both positive touching and partial massage, $90 \%$ described facilitated tucking and $85 \%$ mentioned nesting.

These improvements continued through the follow-up phase $(\mathrm{P} \leq 0.0001)$, where 97.1\% and $94.1 \%$ of the study sample described non-nutritive sucking and positive touching as non-pharmacological pain management methodologies in newborns, followed by oral sucrose $(82.4 \%)$ and facilitated tucking $(82.4 \%)$.

While the percentages decreased during the follow-up phase, they were still significantly higher than pre-intervention phase.

Table (3): presented total scores of nurses' knowledge regarding non-pharmacological management of pain in newborns. It indicated that none of the studied nurses had satisfactory pre-intervention knowledge about such methods.

The post-intervention phase showed statistically significant $(\mathrm{P} \leq 0.0001)$ improvements in all areas of knowledge regarding non-pharmacological pain management (95\%); nonpharmacological management during injections, heel stick, cannulation (52.5\%); nonpharmacological management during insertion of chest, umbilical and endotracheal tubes $(52.5 \%)$.

These improvements continued through the follow-up phase $(\mathrm{P} \leq 0.0001)$ in most

areas, reaching $70.6 \%$ in non-pharmacological management of pain

Figure (1): Displayed total scores of satisfactory nurses' knowledge regarding pain and methods of non-pharmacologic management in newborn. It clarified that none of the studied nurses had satisfactory pre-intervention knowledge. However, more than half of the nurses $(60 \%)$ had satisfactory post-intervention knowledge. These improvements were statistically significant $(\mathrm{P} \leq 0.001)$. 
Table (1): characteristics of the studied nurses

\begin{tabular}{|c|c|c|}
\hline Socio-demographic characteristics & $\begin{array}{r}\text { No. } \\
(n=40)\end{array}$ & $\%$ \\
\hline \multicolumn{3}{|l|}{ Age (years): } \\
\hline $20-<25$ & 25 & 62.5 \\
\hline $25-\leq 30$ & 15 & 37.5 \\
\hline Mean \pm SD & \multicolumn{2}{|c|}{$24.4 \pm 2.4$} \\
\hline \multicolumn{3}{|l|}{ Education level: } \\
\hline Baccalaureate nursing degree. & 6 & 15.0 \\
\hline Technical nursing institute. & 23 & 57.5 \\
\hline Secondary nursing school. & 11 & 27.5 \\
\hline \multicolumn{3}{|l|}{ Marital status: } \\
\hline Single. & 15 & 37.5 \\
\hline Married. & 23 & 57.5 \\
\hline Divorced/widowed. & 2 & 5.0 \\
\hline \multicolumn{3}{|l|}{ Have children $(n=25)$ : } \\
\hline No. & 6 & 24.0 \\
\hline Yes. & 19 & 76.0 \\
\hline \multicolumn{3}{|l|}{ Experience in NICU / years: } \\
\hline$<1$ & 3 & 7.5 \\
\hline $1-<3$ & 24 & 60.0 \\
\hline $3-<6$ & 4 & 10.0 \\
\hline 6 or more & 9 & 22.5 \\
\hline \multicolumn{3}{|l|}{$\begin{array}{l}\text { Number of courses attended about non- } \\
\text { pharmacological pain management in newborns: }\end{array}$} \\
\hline No. & 28 & 70.0 \\
\hline Yes (once). & 12 & 30.0 \\
\hline
\end{tabular}


Table (2): Nurses' knowledge about non-pharmacological management of pain in newborns.

\begin{tabular}{|c|c|c|c|c|c|c|c|c|}
\hline \multirow{3}{*}{ Knowledge } & & \multicolumn{5}{|c|}{ Program phases } & \multirow{3}{*}{$\begin{array}{r}X^{2} \\
\text { (P. value) } \\
\text { Pre-/Post- }\end{array}$} & \multirow{3}{*}{$\begin{array}{r}X^{2} \\
\text { (P. value) } \\
\text { Pre- } \\
\text { Follow-up }\end{array}$} \\
\hline & & Pre- & \multicolumn{2}{|r|}{ Post- } & \multicolumn{2}{|c|}{ Follow-up } & & \\
\hline & $\begin{array}{r}\text { No. } \\
(n=40)\end{array}$ & $\%$ & $\begin{array}{r}\text { No. } \\
(n=40)\end{array}$ & $\%$ & $\begin{array}{r}\text { No. } \\
(n=34)\end{array}$ & $\%$ & & \\
\hline $\begin{array}{l}\text { Definition of non - } \\
\text { pharmacological } \\
\text { management. }\end{array}$ & 6 & 15.0 & 40 & $\begin{array}{r}100 . \\
0\end{array}$ & 34 & 100.0 & $\begin{array}{r}59.130 \\
\left(0.0001^{*}\right)\end{array}$ & $\begin{array}{r}53.470 \\
(0.0001 *)\end{array}$ \\
\hline $\begin{array}{l}\text { Methods of non- } \\
\text { pharmacological } \\
\text { management }^{\neq}\end{array}$ & & & & & & & & \\
\hline Oral sucrose. & 6 & 15.0 & 38 & 95.0 & 28 & 82.4 & $\begin{array}{r}50.725 \\
(0.0001 *)\end{array}$ & $\begin{array}{r}32.739 \\
(0.0001 *)\end{array}$ \\
\hline $\begin{array}{l}\text { Non-nutritive } \\
\text { sucking. }\end{array}$ & 12 & 30.0 & 39 & 97.5 & 33 & 97.1 & $\begin{array}{r}39.432 \\
\left(0.0001^{*}\right)\end{array}$ & $\begin{array}{r}34.679 \\
\left(0.0001^{*}\right)\end{array}$ \\
\hline Swaddling. & 2 & 5.0 & 38 & 95.0 & 21 & 61.8 & $\begin{array}{r}64.800 \\
(0.0001 *)\end{array}$ & $\begin{array}{r}27.646 \\
(0.0001 *)\end{array}$ \\
\hline Soothing vocalization. & 0 & 0.0 & 28 & 70.0 & 15 & 44.1 & $\begin{array}{r}43.077 \\
(0.0001 *)\end{array}$ & $\begin{array}{r}22.134 \\
(0.0001 *)\end{array}$ \\
\hline $\begin{array}{l}\text { Auditory materials } \\
\text { (Toy Sound or Soft } \\
\text { Music) }\end{array}$ & 1 & 2.5 & 27 & 67.5 & 6 & 17.6 & $\begin{array}{r}37.143 \\
(0.0001 *)\end{array}$ & $\begin{array}{r}4.923 \\
\left(0.043^{*}\right)\end{array}$ \\
\hline $\begin{array}{l}\text { Baby's perfume on } \\
\text { nurse's hand. }\end{array}$ & 0 & 0.0 & 12 & 30.0 & 1 & 2.9 & $\begin{array}{r}14.118 \\
(0.0001 *)\end{array}$ & $\begin{array}{r}1.193 \\
(0.459)\end{array}$ \\
\hline Positive touching. & 4 & 10.0 & 37 & 92.5 & 32 & 94.1 & $\begin{array}{r}54.484 \\
\left(0.0001^{*}\right)\end{array}$ & $\begin{array}{r}52.055 \\
\left(0.0001^{*}\right)\end{array}$ \\
\hline Facilitated tucking. & 0 & 0.0 & 36 & 90.0 & 28 & 82.4 & $\begin{array}{r}65.455 \\
(0.0001 *)\end{array}$ & $\begin{array}{r}52.992 \\
(0.0001 *)\end{array}$ \\
\hline Holding. & 2 & 5.0 & 33 & 82.5 & 19 & 55.9 & $\begin{array}{r}48.813 \\
(0.0001 *)\end{array}$ & $\begin{array}{r}23.410 \\
\left(0.0001^{*}\right)\end{array}$ \\
\hline Rhythmic rocking. & 3 & 7.5 & 33 & 82.5 & 20 & 58.8 & 45.455 & 22.600 \\
\hline
\end{tabular}


Port Said Scientific Journal of Nursing $\quad$ Vol.6, No.3, December 2019, Special Issue

\begin{tabular}{|c|c|c|c|c|c|c|c|c|}
\hline & & & & & & & $(0.0001 *)$ & $\left(0.0001^{*}\right)$ \\
\hline Partial massage. & 7 & 17.5 & 37 & 92.5 & 17 & 50.0 & $\begin{array}{r}45.455 \\
(0.0001 *)\end{array}$ & $\begin{array}{r}8.858 \\
\left(0.003^{*}\right)\end{array}$ \\
\hline Breast milk by bottle. & 4 & 10.0 & 30 & 75.0 & 18 & 52.9 & $\begin{array}{r}34.578 \\
(0.0001 *)\end{array}$ & $\begin{array}{r}16.222 \\
(0.0001 *)\end{array}$ \\
\hline Breast feeding. & 2 & 5.0 & 33 & 82.5 & 25 & 73.5 & $\begin{array}{r}48.813 \\
(0.0001 *)\end{array}$ & $\begin{array}{r}37.245 \\
(0.0001 *)\end{array}$ \\
\hline Nesting. & 0 & 0.0 & 34 & 85.0 & 20 & 58.8 & $\begin{array}{r}59.130 \\
(0.0001 *)\end{array}$ & $\begin{array}{r}32.244 \\
(0.0001 *)\end{array}$ \\
\hline Skin to skin contact. & 1 & 2.5 & 30 & 75.0 & 16 & 47.1 & $\begin{array}{r}44.292 \\
(0.0001 *)\end{array}$ & $\begin{array}{r}20.621 \\
(0.0001 *)\end{array}$ \\
\hline $\begin{array}{l}\text { Decrease light and } \\
\text { noise. }\end{array}$ & 6 & 15.0 & 32 & 80.0 & 22 & 64.7 & $\begin{array}{r}33.885 \\
\left(0.0001^{*}\right)\end{array}$ & $\begin{array}{r}19.305 \\
(0.0001 *)\end{array}$ \\
\hline Music. & 0 & 0.0 & 32 & 80.0 & 15 & 44.1 & $\begin{array}{r}53.333 \\
(0.0001 *)\end{array}$ & $\begin{array}{r}22.134 \\
(0.0001 *)\end{array}$ \\
\hline Adequate sleep. & 0 & $\mathbf{0 . 0}$ & 20 & 50.0 & 13 & 38.2 & $\begin{array}{r}26.667 \\
(0.0001 *)\end{array}$ & $\begin{array}{r}18.554 \\
0.0001 *\end{array}$ \\
\hline
\end{tabular}


Table (3): Total scores of nurses' knowledge regarding non-pharmacological management of pain in newborns.

\begin{tabular}{|c|c|c|c|c|c|c|c|c|}
\hline \multirow{3}{*}{$\begin{array}{l}\text { Total scores of } \\
\text { satisfactory } \\
\text { knowledge }\end{array}$} & \multicolumn{6}{|c|}{ Program phases } & \multirow{3}{*}{\begin{tabular}{|l}
$X^{2}$ \\
(P. value) \\
Pre- \\
/Post-
\end{tabular}} & \multirow{3}{*}{$\begin{array}{l}X^{2} \\
\text { (P. value) } \\
\text { Pre- } \\
\text { Follow-up }\end{array}$} \\
\hline & \multicolumn{2}{|l|}{ Pre- } & \multicolumn{2}{|l|}{ Post- } & \multicolumn{2}{|c|}{ Follow-up } & & \\
\hline & $\begin{array}{l}\text { No. } \\
(n=40)\end{array}$ & $\%$ & $\begin{array}{l}\text { No. } \\
(n=40)\end{array}$ & $\%$ & $\begin{array}{l}\text { No. } \\
(n=34)\end{array}$ & $\%$ & & \\
\hline $\begin{array}{l}\text { Non-pharmacological } \\
\text { management of pain. }\end{array}$ & 0 & 0.0 & 38 & $\begin{array}{l}95 . \\
0\end{array}$ & 24 & $\begin{array}{l}70 . \\
6\end{array}$ & $<0.0001^{*}$ & $<0.0001 *$ \\
\hline $\begin{array}{l}\text { Non-pharmacological } \\
\text { management during } \\
\text { injections, heel stick and } \\
\text { cannulation. }\end{array}$ & 0 & 0.0 & 21 & $\begin{array}{l}52 . \\
5\end{array}$ & 8 & $\begin{array}{l}23 . \\
5\end{array}$ & $<0.0001^{*}$ & $0.001 *$ \\
\hline $\begin{array}{l}\text { Non-pharmacological } \\
\text { management during } \\
\text { suction from nose, } \\
\text { endotracheal intubation } \\
\text { and changing tape. }\end{array}$ & 0 & 0.0 & 11 & $\begin{array}{l}27 . \\
5\end{array}$ & 2 & 5.9 & $<0.0001 *$ & 0.208 \\
\hline $\begin{array}{l}\text { Non-pharmacological } \\
\text { management during } \\
\text { insertion of chest, } \\
\text { umbilical and } \\
\text { endotracheal tubes. }\end{array}$ & 0 & 0.0 & 21 & $\begin{array}{l}52 . \\
5\end{array}$ & 13 & $\begin{array}{l}38 . \\
2\end{array}$ & $<0.0001^{*}$ & $<0.0001 *$ \\
\hline
\end{tabular}




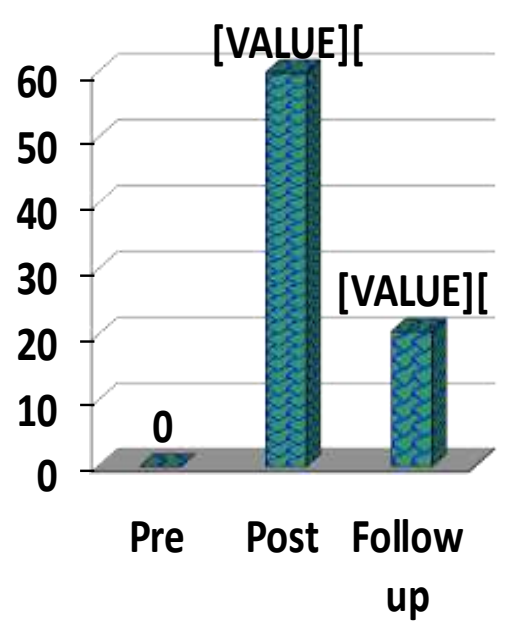

Figure (1) Total scores of satisfactory nurses' knowledge

\section{DISCUSSION:}

Newborns are exposed to a variety of painful procedures in the neonatal intensive care unit (NICU) (Platt, 2014; Leng et al., 2016) like heel stick, venipuncture, intravenous cannula insertion, intubation, suctioning, chest tube insertion/removal, injections (Farshi et al., 2016).

The implementation of the current study intervention led to improvements in nurses' knowledge. Thus, by the end of the intervention, the studied nurses had satisfactory knowledge. This pointed to the effectiveness of the educational program in achieving one of the study objectives. This improvement was most likely attributed to the contents of the program which were based on nurses' identified needs and priorities, the simplicity of the language, and avoiding purely scientific terms that could have made the nurses reluctant to learn. These findings were in accordance with those of Christoffel et al. (2016), who demonstrated the benefit of educational programs (including lectures, courses, clinical protocols and audits) and that they can positively change the knowledge of healthcare professionals regarding pain management. This was in line with ElHusseiny (2013) in Egypt, who stated that nurses had knowledge about different methods of non-pharmacological management of pain in newborns. This was also supported by Aymar et al. (2014) in Brazil, who found that most healthcare professionals knew the management protocols for neonatal pain. On the other hand, these results did not agree 
with those of Al Qadire and Al Khalaileh (2014) in Jordan, who indicated that nurses were less knowledgeable about pain management than their international counterparts. Abdalrahim et al. (2011) also indicated that nurses had misconceptions and inadequate knowledge regarding pain management in newborns.

The current study illustrated that before the educational program, none of the studied nurses knew the following non-pharmacological pain management procedures; swaddling, tucking, nesting, holding, rhythmic rocking, baby's perfume on nurse's hand and using auditory materials. This could have been attributed to the studied nurses did not update their knowledge regarding pain management in newborns. The results of MacDonald and Seshia (2015) agreed with these findings, and mentioned the following methods as non-pharmacological interventions for newborns' pain management: facilitated tucking, swaddling, multisensorial stimulation, auditory recognition and music therapy.

Regarding nurses' knowledge about non-pharmacological management of pain in newborns in all determined painful procedures in post-intervention and follow up phases, the most frequent mentioned methods were: NNS, oral sucrose, positive touching and partial massage. This may have been due to that it was easy to remember these methods from the educational program.

These findings were further supported by Costa et al. (2017), who showed that the most frequent methods cited among the studied nurses were: oral glucose, NNS and positioning. Also, Christoffel et al. (2016) illustrated that the participants in his study recognized the effectiveness of breastfeeding and oral sucrose in pain-reducing procedures however, skin-to-skin contact and massaging were less recognized.

\section{CONCLUSION:}

Based on the findings of the current study, it can be concluded that after the educational program, more than half of the studied nurses had satisfactory knowledge regarding methods of non-pharmacological management in newborns. The most frequent methods mentioned in post-intervention and follow up phases were: NNS, oral sucrose, positive touching and partial massage 


\section{RECOMMENDATIONS:}

Based on the findings of the present study, the following recommendations are suggested:

1. Continuous training programs should be provided for nurses in the NICUs to keep their knowledge regarding non-pharmacological pain management in newborns upto-date.

2. Updated simple Arabic handouts about non-pharmacological pain management in newborns should be available in all NICUs.

3. Encouraging nurses to attend national and international conferences, and workshops about non-pharmacological pain management in NICUs.

\section{REFERENCES:}

Abdallah, B., Badr, L.K. and Hawwari, M. (2013): The efficacy of massage on short and long term outcomes in preterm infants, Journal of Infant Behavior \& Development; 36(4):662-669.

Abdalrahim, M.S., Majali, S.A., Stomberg, M.W. and Bergbom, I. (2011): The effect of postoperative pain management program on improving nurses knowledge and attitudes toward pain, Journal of Nurse Education in Practice;11 (4):250-255.

Al Qadire, M. and Al Khalaileh, M. (2014): Jordanian nurses knowledge and attitude regarding pain management. Pain Management Nursing; 15(1):220-228.

Aymar, C.L., Lima, L.S., Santos, C.M., Moreno, E.A. and Coutinho, S.B. (2014): Pain assessment and management in the NICU: analysis of an educational intervention for health professionals. Pediatrics (Rio J);90(3):308-15.

Bellieni, C.V., Tei, M. and Buonocore, G. (2016): Contextualized pain management in newborns. Journal of Maternal-Fetal \& Neonatal Medicine; 5(2). 
Chidambaram, A.G., Manjula, S., Adhisivam, B. and Bhat, B.V. (2014): Effect of kangaroo mother care in reducing pain due to heel prick among preterm neonates: a crossover trial, J Matern Fetal Neonatal Med; 27:488

Christoffel, M.M., Castral, T.C., Dare, M.F., Montanholi, L.L. and Scochi, C.G. (2016): Knowledge of healthcare professionals on the evaluation and treatment of neonatal pain. Rev Bras Enferm 69(3):516-22.

Costa, T., Rossato, L.M., Bueno, M., Secco, I.L., Sposito, N.P.B., Harrison, D. and Freitas, J.S. (2017): Nurses' knowledge and practices regarding pain management in newborns. Rev Esc Enferm USP.;51:e03210.

Craig, J.W., Glick, C., Phillips, R., Hall, J.S., Smith, J. and Browne, J. (2015): Recommendations for involving the family in developmental care of the NICU baby. Journal of Perinatology; 35:55-58.

El-Husseiny, H.S. (2013): Nurses' knowledge about physiological and behavioral pain indicators of newborn in Port-Said, published master these, Faculty of Nursing, Port Said University.

Farshi, M.R., Jabraeili, M., Sabouhi, R. and Ghorbani, F. (2016): Cumulative stressors in preterm infants hospitalized in neonatal intensive care units. Nurs Midwifery Stud.

Hall, R.W. (2012): Anesthesia and analgesia in the NICU. Clin Perinatol.; 39(1):239254.

Kliegman, R.M., Stanton, B.F., Geme, S.J., Schor, N.F. and Behrman, R.E. (2016); Nelson textbook of pediatrics, $19^{\text {th }}$ ed. Philadelphia, Publisher, Elsevier Saunders.

Leng, H.Y., Zheng, X.L., Zhang, X.H., He, H.Y., Tu, G.F., Fu, Q., Shi, S.N. and Yan, L. (2016): Combined non-pharmacological interventions for newborn pain relief in two degrees of pain procedures: a randomized clinical trial. European Journal of Pain; 20(6):989-97. 
MacDonald, M.G. and Seshia, M.K. (2015): Avery's neonatology, pathophysiology and management of the newborn-LWW.

National Association of Neonatal Nurses (2012): newborn pain assessment and management: Guideline for practice, Chicago, America

Naughton, K. A. (2013): The combined use of sucrose and nonnutritive sucking for procedural pain in both term and preterm neonates. Advances in Neonatal Care;13(1)، 9-19.

Phillips, R.M. (2015): Seven core measures of neuroprotective family-centered developmental care: Creating an infrastructure for implementation. Newborn \& Infant Nursing Reviews; 15(3): 87-90.

Platt, M.J. (2014): Outcomes in preterm infants. Public Health 128:399-403.

Roofthooft, D.W., Simons, S.H., Anand, K.J., Tibboel, D. and van Dijk, M. (2014): Eight years later, are we still hurting newborn infants? Neonatology; 105(3):218-226.

Walden, M. and Gibbins, S. (2013): Pain assessment and management: guideline for practice, $3^{\text {rd }}$ ed., Glenview, IL, , National Association of Neonatal Nurses. 
تأثير برنامج تعليمي على معلومات ممرضات الأطفال عن العلاج غير الدوائي للألم فى وحدات الرعاية المركزة لحديثي الولادة

\begin{abstract}
أ.د أمل أحمد خليل / د. نبيلة حسن عبد اللاه/ د. نجوي رزق محمد / م.م. هالة سمير الحسيني

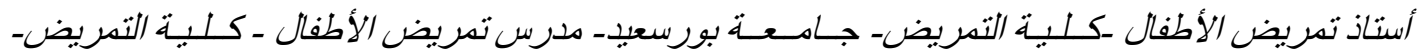

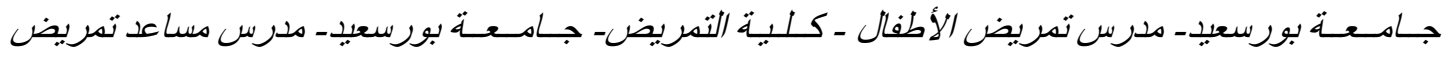

الأطفال ـكليبة التمريض- جـامسعـة بورسعبي
\end{abstract}

\title{
الخـلاصــة
}

يتعرض حديثي الو لادة للعديد من الإجر اءات المؤلمة خلال فترة العلاج بوحدات الرعاية المركزة للمو اليد، في حين ان استخدام طرق العلاج غير الدوائي يمنع ويقلل من هذا الألم. هدفت هذه الدراسة إلي معرفة اثر برنامج تعليمي علي معلومات ممرضات الأطفال عن العلاج غير الدوائي للألم فى وحدات الرعاية المركزة لحديثي الو لادة. أجريت هذه الدراسة شبه التجرييية علي جميع الممرضات اللاني كن يعملن في وحدات الرعاية المركزة لحديثي الولادة بمستشفيات بورسعيد (40 ممرضة) وقد تم جمع البيانات باستخدام استمارة إستبيان. وقد أظهرت نتائج هذه الدراسة أن معلومات الممرضات عن طرق العلاج غير الدو ائي للألم في حديثي الولادة كانت غير كافية قبل تطبيق البرنامج التعليمي، بينما بعد تطبيقه أصبحت لديهن معلومات جيدة عن طرق العلاج غير الدوائي. وقد أوصت هذه الدراسة بضرورة أن يكون طاقم التمريض القائم برعاية حديثي الولادة على دراية ومدرب على طرق العلاج غير الدوائي للألم لحديثي الولادة من خلال البرامج التدريبة المستمرة، والمؤتمرات سواء المحلية أو الدولية، بالإضافة إلى ورش العمل حول تقييم وطرق العلاج غير الدوائي للألم في حديثي الولادة.

الكلمات المرشدة: غير الدوائي، علاج الألم، وحدات الرعاية المركزة لحديثي الولادة، ممرضات الأطفال، برنامج تعليمي 